\title{
Transforming the Ich-Du to the Ich-Es: The Migrant as “Terrorist” in Kabir Khan's New York and Kamila Shamsie's Home Fire
}

\section{ABSTRACT}

Terror narratives have been characterized by a dialogism where the "normative" I-i.e. the "non-threatening mainstream"-defines and delineates subjects whose identity is centred on their (actual or presumed) location in the terror network. This is especially so in the case of Asian migrants who settle down in Western countries, as their very identity as Asian locates them at a precarious point in the real or imagined "terror network." The migrant is no longer the $D u$ (Thou), but the Es (It), imparting an identity to the $I c h(\mathrm{I})$, where the Ich denotes the "original" citizens of the country. The transactions of the "I" with the "Thou" and the "It" become significant in the context of Asian immigrants in that, for the dominant mainstream (the "I"), the "terrorist" is an Es/"It" that has gradually marked its transition from the $D u /$ "Thou." The person of the "terrorist" finds its ontological properties from the gradual movement away from a "Thou" to an "It." The hitherto unbounded "Thou" is transformed into a definable "It," by ascribing to her/him a religion, race, colour, nationality and ethnicity. $\mathrm{He} /$ she is not confronted, as every "Thou" is, but is rather "experienced" as a source of terror, as an "It." The paper attempts to explore the transformation of the figure of the "migrant terrorist" from a confronted "Thou" to an "imagined/experienced" "It" through an analysis of New York (2009) by Kabir Khan and Home Fire (2017) by Kamila Shamsie.

Keywords: Ich-Du, Ich-Es, Asian migrant, terror narratives, objectification, pathologizing gaze. 
"For the $I$ of the primary word $I$-Thou is a different $I$ from that of the primary word I-It."

(Buber 3)

Terror narratives have been characterized by a dialogism where the "normative" I-i.e. the "non-threatening mainstream"-defines and delineates subjects whose identity is centred on their (actual or presumed) location in the terror network. The location becomes all the more significant when the subject is an already "othered" entity, marked by her/his status as a migrant in a foreign country. This is especially so in the case of Asian migrants who settle down in Western countries, as their very identity as Asian locates them at a precarious point in the real or imagined "terror network." The Asian "other," i.e. the potential terrorist, assumes her/ his identity in opposition to that of the "non-threatening" mainstream, i.e. those who "belong" to the country. The migrant is no longer the $D u$ (Thou), but the Es (It), imparting an identity to the Ich (I), where the Ich denotes the "original" citizens of the country or the others who conform to the norms of the state.

The transformation of the "Thou" into the "It" is nowhere more evident than in terror narratives featuring Asian migrants in the West, where migrants are often stereotyped as terrorists, especially when they are Muslims. The mainstream identifies itself through its distinction from the now-bounded entity called the "It," the "migrant," the "terrorist." $\mathrm{He} / \mathrm{she}$ is not confronted, as every "Thou" is, but is rather "experienced" as a source of terror, as an "It." The paper attempts to explore the transformation of the figure of the "migrant terrorist" from a confronted $D u /$ "Thou" to an "imagined/experienced" Es/"It" through an analysis of New York ${ }^{1}$ (2009) by Kabir Khan and Home Fire ${ }^{2}$ (2017) by Kamila Shamsie. The works have

1 A 2009 film directed by Kabir Khan, New York portrays the modes in which Asian subjects are pathologized as "terrorists." Samir, an American-Asian Muslim, is arrested on false charges of terrorism after the 9/11 attacks and the third-degree torture leaves him traumatized. Years later, an FBI team, led by Roshan, another Asian Muslim who had been living in the US for two decades, arrests Samir's former friend, Omar, who is also a Muslim from India, in order to spy on Samir. Omar stays in Samir's house and gradually realizes that the latter is involved in terrorist activities in order to take revenge upon the system which had victimized him. Samir and his wife are later killed by the FBI and Omar adopts their son, Danyal.

2 Kamila Shamsie's Home Fire, published in 2017, engages with the issue of terrorism and the response of the "homeland" towards suspected terrorists who are "outsiders." The story is set in Britain and the major characters, Isma and her twin siblings, Aneeka and Parvaiz, are naturalized British citizens. As the children of a Pakistani-British jihadist who died while being deported to Guantanamo Bay, they live under surveillance all their lives, under the watchful gaze of the British security forces. However, Parvaiz joins ISIS 
been chosen since both engage with an issue that has always haunted and continues to haunt the Western imaginary even today-the "danger" posed by the "Asian Other," especially a Muslim subject from the "exotic, yet dangerous" East. The conferral of an "extrareal and phenomenologically reduced status ... to the Orient and Islam" (Said 57) and the exoticization of the two entities acquired a dangerous edge with the 9/11 attacks and the rise of ISIS, with Islamic subjects, especially those from the Orient, being viewed as threats to the "civilized" West. The works challenge the reader to map the modes in which violence is unleashed on the "Other" in order to prevent a violent ideological decolonization as envisaged by Fanon in The Wretched of the Earth (1961), which would enable them to exist as "Thou" to be confronted. The violence inflicted on the Asian Muslim subject, irrespective of their citizenship or loyalty to the "homeland," transforms her/him into an imagined, "dangerous" entity to be pathologized as an "It."

Buber's elaboration of the transactions of the "I" with the "Thou" and the "It" becomes significant in the context of Asian immigrants in that, for the dominant mainstream (the "I"), the "terrorist" is an Es/ "It" that has gradually marked its transition from the $D u$ / "Thou." In both New York and Home Fire, the protagonists are immigrants from South Asian countries, who are constantly under state surveillance, and perceived as potential threats to the stability of the social order. The migrant, who has already moved from the status of $D u$ to $E s$, by virtue of her/his alienation in the country of settlement, becomes doubly objectified by the pathologizing gaze of the West which perceives Asians as potential terrorists. In both works under consideration, the Islamophobia that followed the 9/11 attacks and the establishment of the ISIS Caliphate led to drastic actions on the part of the state against Muslim citizens, especially Asian Muslims. In New York, Samir is arrested and taken to a detention centre owing to his status as a Muslim Indian in America, which made him a suspect. $\mathrm{He}$ says: "The FBI had arrested 1200 people like me and put them in different jails. We had just one thing in common ... our religion." In Home Fire too, a systematic targeting of Muslims and their labelling as "terrorists" is

and Isma reports it to the security forces, which leads to the souring of the relationship between the two sisters. Aneeka's attempts at saving Parvaiz fail and he is killed in a driveby shooting near the British consulate in Istanbul, right as he was about to confess his acts and find a way to escape to Britain. Since Karamat Lone, the Home Minister (who was also a Pakistani Muslim who had obtained British citizenship), had implemented policies that led to the denaturalization of Parvaiz, Britian refuses to repatriate his body which is then sent to Pakistan. Aneeka fights to get his body back to his "homeland," Britain, and meets with fierce opposition from the state. She then goes to Pakistan and sits with his body in a public park, seeking justice. She, along with her lover Eamonn Lone (Karamat Lone's son), are killed in a bomb blast in the park. 
evident in the case of the Pashas. Despite the lack of concrete proof against Adil Pasha, he is taken to Guantanamo and there are no written records of the event. The life of a Muslim subject becomes insignificant, turning him into a bomo sacer- "life that cannot be sacrificed, yet may be killed" (Agamben 169-70), existing in a state of exception. The transformation of the subject into a bomo sacer is preceded by his gradual movement from a $D u$ to an $E s$ from which the person of the "terrorist" finds its ontological properties. The hitherto unbounded "Thou" is transformed into a definable "It," by ascribing to her/him a religion, race, colour, nationality and ethnicity. Despite identifying themselves as American/British subjects and reiterating the "fact" of their citizenship and loyalty repeatedly, the state perceives Samir, Aneeka and Parvaiz as Asian Muslims lacking loyalty to the country which they claim to be their own. They are not "confronted" as persons, but rather experienced as "objects" of terror.

Citizenship becomes a pivotal point around which the transformation from an $I c h-D u$ to $I c h-E s$ takes place. In general, citizenship is a contested issue with multiple significations: "citizenship as a legal status, citizenship as a bundle of rights and entitlements, and citizenship as a sense of identity and belonging" (Jayal 2). For Asian migrants in the West, acquiring citizenship in the new country is an act with these and other layers of signification. Most potently, it is an act whereby they can proclaim themselves as "safe" subjects who wish to identify with the state. This act became particularly significant in the wake of the proliferation of terrorism as even second and third generation migrants had to repeatedly proclaim their loyalty to the state in order to gain access to basic rights and dignity. We frequently observe Samir, Parvaiz and Aneeka reiterating their status as American/ British citizens when accosted by the FBI or MI5, pointing to how Muslim migrants consider citizenship an imperative for their security. The granting of citizenship is perceived as an act of largesse by the "exalted" Western country. The Home Secretary's repeated assertion that "Citizenship is a privilege, not a right or birthright" (Shamsie 198), especially with regard to Muslim migrants, and the constant threats of revoking the citizenship of non-normative subjects testifies to the high-handedness of the state in its treatment of migrants. With their citizenship itself under threat, they are denied job opportunities and a dignified life, and are pushed to the margins. Through access to or denial of citizenship, the state enters into an Ich-Es relationship with them, marking them as "objects," as different from the $D u$, i.e. the "pure" citizens who are considered "persons." Ronald Smith, in his introduction to Martin Buber's I and Thou (1937) asserts:

There is ... a radical difference between a man's attitude to other men and his attitude to things. The attitude to other men is a relation 
between persons, to things it is a connexion with objects ... The other person, the Thou, is shown to be a reality-that is, it is given to me, but it is not bounded by me... The world of objects or things, on the other hand, presupposes a single centre of consciousness, one subject, an $I$ which experiences, arranges, and appropriates ... when a Thou is truly confronted, it becomes an It. (Buber vii)

The Muslim subject, when transformed from a $D u$ to an $E s$ by the Islamophobic Western consciousness, becomes an object to be "experienced, arranged and appropriated" (Buber vii) by the normative "pure" subjects. Eamonn's British friends, when they detect his aloofness, are quick to tease him saying "we may need to alert the authorities" (Shamsie 82), pointing to how a hitherto admired subject can be converted into an object of suspicion that must be "appropriated" and "disciplined." Similarly, Omar is chosen as the FBI spy owing to his status as a Muslim migrant who aspires to integrate with the American state. Roshan, also an Asian Muslim, is given charge of Samir's case, owing to his ethnic and religious identity. The state appropriates compliant subjects, who themselves belong to the category of the $E s$, in order to pursue its agenda.

In both works, Muslim migrants are "constructed" as terrorists by the state policies which marginalize the community and by the Islamophobia that came to dominate the Western world in the aftermath of 9/11. Samir is arrested and detained in an undisclosed location much like Guantanamo, with the photos of the World Trade Centre he had taken for a university paper considered the only evidence of his terrorist activity. Mere suspicion is taken as proof of his guilt and third-degree torture is inflicted upon him. The condemnation of the Muslim man as a bomo sacer who is perpetually in a state of exception, functioning as a body where the state can exercise unlimited power without being questioned, is evident here. In order to ensure that public sentiment does not turn in favour of Parvaiz, the British officials propagate the news that he was about to carry out a terrorist attack on the British Consulate although they had been informed that he was trying to come back "home." The process becomes easier as the subject is a Muslim immigrant, who the civil society is more than happy to construe as a terrorist to propagate Islamophobia. He is denied dignity even in death as the British government does not allow the cremation of his body in Britain with the Home Secretary taking an adamant stance on the issue of his citizenship. The Es is thus created by being made stateless and he becomes an object to be experienced by the "true Englishman" (214).

Buber remarks: "Every It is bounded by others; It exists only through being bounded by others" (4). This sense of being bound takes on multiple 
significations with the migrant being bounded in the sense of being restricted and in the sense of being the receptor of an identity proffered by others. The migrant seemingly exists as a foil to the normative "citizen" of the country, perceived as a threat to the latter. Both New York and Home Fire portray several instances of British/Americans spitting on the protagonists or spewing hatred in a very explicit manner after 9/11. By the same token, Parvaiz's disappearance is an act which the state supports silently as the intention is to project the migrants as subjects "deserving" punishment for their deviance. The subjects' identity as Muslims and as Asian immigrants is made conspicuous, making it easier to label them as "terrorists," thereby providing them a pathologized identity. The restrictions imposed on their movements and the subtle ways in which they are excluded from the politico-jural domain facilitate their movement from the status of the $D u$ to that of the $E s$, as in the case of Samir, who is rejected in interviews, and Isma and Aneeka, who are often denied visas and are harassed in interrogation rooms.

The perception of the Muslim as the other is also necessary for the "pure" citizen to assert his/her normativity. The "I" which "experiences" the object separates the latter from itself. It is in this state that the " $I$ is properly active" (Buber 23). The human consciousness of the Ich perceives the $E s$ as an object separated from it and establishes a barrier between the two. This process is visible in the modes in which the Muslim subjects are set apart as mere objects against which the normative American/British citizen asserts his/her identity as a "safe" subject loyal to the state. For instance, in New York, Omar unconsciously attempts to mark Samir as having been totally different from him since college. While Omar is a shy, quiet boy, Samir is projected as a smart, macho hero. Despite being an immigrant, Omar attempts to mark himself as different from the "problematic" subject by subtly highlighting their differences, with him being more reserved, "obedient" (implying that he is less prone to deviant activities than Samir) and cautious. Here, he defines himself as an "I" through the act of separation from the object-the Muslim man labelled a terrorist. Isma's and Karamat Lone's attempts at integration are also acts meant to separate the "I" from the world of objects/Es, constituted by "other" Muslims. Isma denounces Parvaiz to the state in an attempt to create a safe space for herself and Aneeka, and reads a statement saying that neither she nor her sister would go to his funeral in Pakistan in order to draw a clear boundary between themselves and their jihadi brother. Lone is ashamed of his Pakistani origins and is embarrassed about his Muslim identity, which propels him to take actions against Muslims in order to prove his impeccability. The Muslim "other" becomes the Es against which Isma and Lone define themselves as the Ich. The situation here is ironic 
in that they themselves belong to the Es from which they try to separate themselves. What might have been a $D u$, if they were not migrants, is transformed into an Es in order to ensure the survival of the "I."

The Es, subjected to the pathologizing gaze of the $I c h$, often resorts to one of two means of reacting-by following the very dangerous trajectory they are often falsely accused of pursuing, or by conforming to the norms laid down by the "I," thankful for the "charity" bestowed upon them by the West by allowing them to be citizens, albeit marginal. Samir coordinates a South Asian sleeper cell in order to take revenge for the injustice perpetrated on him by the US simply because of his Muslim identity. Parvaiz joins the jihadis because of the discontent instilled in him by the way Britain treats its Muslims. His curiosity regarding his father was suppressed by his family so that people would not "start to suspect our sympathies" (Shamsie 49). The family is constantly under surveillance and the state perceives the siblings as potential terrorists. They are pathologized, with their visa applications denied, mobile messages and emails monitored and loyalties questioned in interrogation rooms. The possibility of the government "withdrawing all the benefits of the welfare state-including state school and the NHS — from any family suspected of siding with the terrorists" (Shamsie 49) functions as a threat, making Parvaiz suppress his desire to know about his father. When Farooq appears as a source through which his wish could be fulfilled, Parvaiz is naturally drawn to him, finally leading to his joining ISIS. Rather than ensuring that the child of the "terrorist" is provided adequate psychological care and education, the state attempts to suppress him, which ultimately results in rebellion against the state by the body of the homo sacer.

The second mode of negotiating with the state takes the form of absolute conformity to the norms, "understanding the position [they] are in ... accepting the law, even when it's unjust" (Shamsie 196), and lauding the "largesse" of the state. In New York, Roshan tells Omar:

I am a Muslim and yet, I have been given responsibility for a sensitive case like this. That is only possible here [America]. You shouldn't forget that you and I came here as immigrants and now we have found a place here, we've got our freedom and it is to protect this freedom that I am doing all this.

The conforming "I" here becomes a tool of the state owing to his gratitude towards the state for its charity. Karamat Lone in Shamsie's novel also works as an agent for the state as he strongly believes that it was Britain which provided him with an identity. Both subjects believe that they must work to serve the state, even at the cost of their own identity, in order to 
"remove the hatred towards Muslims" (New York). The seeming attempt to protect their community by projecting themselves as one among the Es actually functions as a mode of further distancing the Muslim community from them in order to preserve their status as normative subjects.

The presence of the Muslim immigrant is nevertheless necessary for Western states to maintain their status as "inclusive" countries. As Hegel argues in The Phenomenology of Spirit (1807), "the truth of the independent consciousness is accordingly the servile consciousness of the Bondsman" (qtd. in Ray and Seemin 5). For the normative West to exist as a role model for the world by virtue of its "tolerance" and "inclusiveness," the bondsman, represented by the South Asian Muslim immigrant, is essential. It is only through an affirmation from and through the $E s$ that the $I c h$ can exist. As such, through such acts of "charity" as mentioned above and by giving scholarships to migrants because they "tick their 'inclusive' and 'diverse' boxes" (Shamsie 132), the Es is brought into being as a servile bondsman.

Thus, it is often in the encounter between the majority and the minority, the "normative" and the non-normative, that the migrant perceived as a potential terrorist turns into an "It"-an object-to be experienced. The humanity of the Muslim subject is denied and he is transformed into a bomo sacer who is simultaneously within and outside the juridical domain, always vulnerable to being attacked by the mainstream. They are denied the possibility of even being a $D u /$ "Thou" and assigned the status of an $E s /$ "It" which the normative subjects "experience" and pathologize. As Bill Brown argues in "Thing Theory" (2001), by being foregrounded from against the White non-Muslim community, South Asian Muslim migrants are turned into 'things,' which marks the former as a $D u$, an entity existing in a relational network. As a corollary, the latter are marked as Es, existing as "things" to be experienced and pathologized.

\section{Works Cited}

Agamben, Giorgio. Homo Sacer: Sovereign Power and Bare Life. Translated by Daniel Heller-Roazen. Stanford UP, 1998.

Brown, Bill. "Thing Theory." Critical Inquiry, vol. 28, no. 1, 2001, pp. 1-22. https://doi.org/10.1086/449030

Buber, Martin. I and Thou. Translated by Ronald Gregor Smith. Charles Scribner's Sons, 2006.

Fanon, Frantz. The Wretched of the Earth. Grove, 1963. Jayal, Niraja Gopal. Citizenship and Its Discontents. Harvard UP, 2013.

New York. Directed by Kabir Khan, performances by John Abraham, Katrina Kaif and Neil Nitin Mukesh, Yash Raj Films, 2009. 
Ray, Raka, and Seemin Qayum. Cultures of Servitude: Modernity, Domesticity and Class in India. Stanford UP, 2009.

Said, Edward W. Orientalism. Pantheon, 1978.

Shamsie, Kamila. Home Fire. Bloomsbury India, 2017.

\section{Minu Susan Koshy currently works as Assistant} Professor in the Department of English, Mar Thoma College for Women, Kerala, India. She has published extensively in national and international journals and has served as the resource person at several conferences. Her areas of interest include cultural studies, postcolonial studies, and comparative and world literatures. Her books include Narrating Childhood Trauma: The Questfor Catharsis (DC Books-Expressions, 2015), a translation of the Malayalam anthology Tattoo (Authorspress, 2015) by Jacob Abraham, an edited collection of poems by Elizabeth Kuriakose, titled Gossamer Reveries (Authorspress, 2019) and Mapping the Postcolonial Domestic in the Works of Vargas Llosa and Mukundan: Tales of the Threshold (Cambridge Scholars Publishing, 2020). An edited volume titled When Objects Write Back: Reconceptualizing Material Culture in the Tricontinent is scheduled to be published by Cambridge Scholars Publishing later this year.

https://orcid.org/0000-0002-9211-5811

minususankoshy@gmail.com

minu.s@marthomacollege.ac.in 